\title{
Microbial facies in a Sturtian cap carbonate, the Rasthof Formation, Otavi Group, northern Namibia
}

\author{
Sara B. Pruss ${ }^{\mathrm{a}, *}$, Tanja Bosak ${ }^{\mathrm{b}}$, Francis A. Macdonald ${ }^{\mathrm{c}}$, Marie McLane ${ }^{\mathrm{a}}$, Paul F. Hoffman ${ }^{\mathrm{c}, \mathrm{d}}$ \\ a Department of Geosciences, Smith College, Northampton, MA 01063, USA \\ ${ }^{\mathrm{b}}$ Department of Earth, Atmospheric and Planetary Sciences, Massachusetts Institute of Technology, Cambridge, MA 02139, USA \\ ${ }^{c}$ Department of Earth and Planetary Sciences, Harvard University, Cambridge, MA 02138, USA \\ d School of Earth and Ocean Sciences, University of Victoria, Victoria, British Columbia, Canada V8W 2 Y2
}

\section{A R T I C L E I N F O}

\section{Article history:}

Received 4 February 2010

Received in revised form 24 May 2010

Accepted 2 June 2010

\section{Keywords:}

Cryogenian

Roll-up structure

Neoproterozoic

Microbialaminite

Cap carbonate

Namibia

\begin{abstract}
A B S T R A C T
Microbial structures in Neoproterozoic cap carbonates record the environmental processes present in the aftermath of global glaciation. The Rasthof Formation of northern Namibia is a unique carbonate depositional sequence that formed during post-glacial transgression and highstand following the Chuos glaciation. Carbon isotope profiles from four examined localities reveal that onlap was diachronous over post-glacial, syn-rift topography. The lower Rasthof Formation consists primarily of dark gray thinly $(<\mathrm{mm})$ and thickly $(1-4 \mathrm{~mm})$ laminated microbialites that exhibit different rheological responses to the emplacement of syndepositional dikes. The thinly laminated microbialaminite facies commonly host cmsized syndepositional folds of microbially laminated sediment called roll-up structures. In more thickly laminated facies, layers are deformed into broad decimeter-sized folds, but roll-up structures are absent. Large syndepositional carbonate clastic dikes (0.5-1 m wide) and smaller veins $(0.1-0.5 \mathrm{~m})$ cut across bedding in both the thinly and thickly laminated facies, but are conspicuously absent from underlying and overlying beds. These carbonate clastic dikes and veins contain convoluted microbial mats and abundant marine cements. The lack of evidence for wave action or current scouring in the form of bedforms, scour marks, or intraclasts indicates that these microbialaminites formed below storm wave base.

The close spatial association of deep-water microbialaminite facies in the Rasthof cap carbonate with carbonate clastic dikes suggests that the emplacement of dikes produced both dm-sized broad folds and $\mathrm{cm}$-scale laterally discontinuous roll-up structures. The emplacement of the dikes, most likely due to the release of fluids into incompletely lithified mats, deformed cement-rich thick laminites into broad folds, while thinly laminated and more slowly lithifying mats were rolled into roll-up structures. Microbialaminite facies in the Rasthof cap carbonate thus not only reflect the depositional and environmental processes that operated in the aftermath of the Sturtian glaciation, but may also provide clues for the formation of roll-up structures found in even older Precambrian carbonates.
\end{abstract}

(C) 2010 Elsevier B.V. All rights reserved.

\section{Introduction}

The Earth experienced at least two global glaciations during the Neoproterozoic, as suggested by the presence of Neoproterozoic diamictites on nearly every paleo-continent, including those at low paleo-latitudes (Evans, 2000; Hoffman and Li, 2009). Neoproterozoic glacial deposits are typically capped by carbonate rocks. In spite of presumably similar mechanisms operating in the aftermath of these two global glaciations (Hoffman and Schrag, 2002), the Sturtian and basal Ediacaran (Marinoan) cap carbonate sequences contain distinct facies that may provide clues to the nature of the environmental conditions and biotic recovery in the aftermath of

\footnotetext{
* Corresponding author. Tel.: +1 4135853948.

E-mail address: spruss@smith.edu (S.B. Pruss).
}

global glaciations. Facies in the comparatively well-studied basal Ediacaran cap carbonate characteristically contain a basal portion composed of a buff to pink colored dolomite that hosts tubestone stromatolites (Cloud et al., 1974; Corsetti and Grotzinger, 2005) and giant wave ripples (Allen and Hoffman, 2005), and an upper limestone that contains pseudomorphosed formerly aragonite crystal fans (Grotzinger and James, 2000; James et al., 2001). Tubestone stromatolites have been described on several paleocontinents and are exposed in Death Valley (Cloud et al., 1974), Namibia (Hegenberg, 1987; Kennedy et al., 2001; Corsetti and Grotzinger, 2005), Brazil (Rodrigues-Nogueira et al., 2003), Mongolia (Macdonald et al., 2009a), and Arctic Alaska (Macdonald et al., 2009b). These microbialites are certainly rare in the geological record, if not unique to basal Ediacaran cap carbonates (Corsetti and Grotzinger, 2005). In contrast, older Cryogenian 'Sturtian' cap carbonates have not been described extensively. In Arctic Alaska 

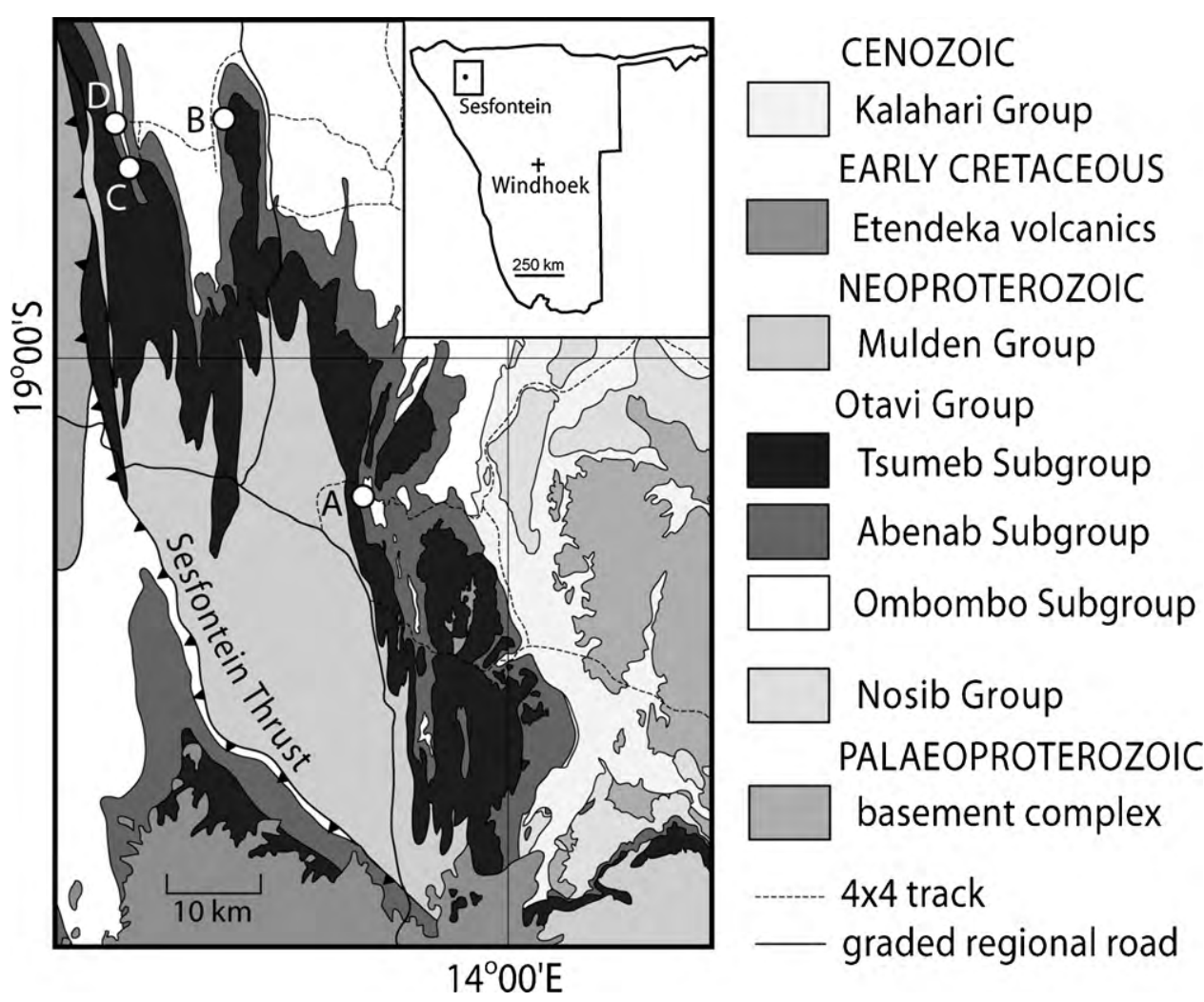

Fig. 1. Geological locality map of study area. Inset of Namibia shows location of locality map in box. (A) Ongongo; (B) Okaaru; (C) South Ombepera; and (D) Ombepera.

(Macdonald et al., 2009b), Mexico (Corsetti et al., 2007), on the Congo Craton of northern Namibia (Hoffman and Halverson, 2008) and on the Kalahari Craton of southern Namibia, Sturtian cap carbonates typically consist of dark microbialaminites. In the Neoproterozoic stratigraphy of northern Namibia, these dark-colored microbialaminites are unique to the Rasthof Formation.

Here we describe two distinct microbialite facies preserved in the Rasthof cap carbonate of northern Namibia on the western platform of the Otavi fold belt. This report focuses on exposures of the Rasthof Formation along an east-west transect off the western margin of the Congo Craton (Fig. 1). Here we use carbon isotope profiles to correlate these sections that contain well-preserved microbial facies. These facies have been described previously at the outcrop scale; the thickly laminated facies that contain 1-4$\mathrm{mm}$ thick light and dark laminae and are commonly folded in $0.1-0.5 \mathrm{~m}$ wide folds were characterized as stromatolites because of the apparent doming of the folds (Hoffman and Halverson, 2008). The thinly laminated ( $<1-\mathrm{mm}$ thick laminae) dark microbialites with roll-up structures have previously been recognized but have not been described in detail (Hoffman and Halverson, 2008). Here we present new field observations and the results of petrographic and geochemical analyses to address the chemical, biological and deformational processes operating in the aftermath of the first global glaciation.

\section{Geologic setting}

The Neoproterozoic Otavi Group is a 2-4-km thick carbonatedominated succession exposed in northern Namibia that was deposited on a rifted passive margin of the Congo Craton (Gevers, 1931; Le Roex, 1941; Hoffmann and Prave, 1996; Hoffman and Halverson, 2008). The Chuos, Rasthof, Gruis and Ombaatjie Formations (not shown) are well-exposed along the western Kamanjab inlier (Fig. 1) and are preserved between erosion surfaces below glacial diamictites of the Chuos and Ghaub Formations (Hoffman et al., 1998; Hoffman and Halverson, 2008). Evidence for syndepositional normal faulting is present in the Chuos, Rasthof, and Gruis Formations (Hoffman and Halverson, 2008). In northern Namibia, the Rasthof Formation (Hedberg, 1979) overlies diamictite and conglomerate of the Chuos Formation of presumed Sturtian age. The age of the Rasthof Formation is constrained below by $746 \pm 2 \mathrm{Ma}$ (U-Pb TIMS zircon age) volcanic rocks in the Naauwpoort Formation (Hoffman et al., 1996) and above by a $635.6 \pm 0.5 \mathrm{Ma}$ (U-Pb TIMS zircon age) rhyolite in the Ghaub Formation (Hoffmann et al., 2004). The Rasthof Formation consists of $200-400$ m of dark gray carbonate preserved in the Otavi fold belt, which rims the Northern Platform (e.g. Miller, 1983; Hoffman et al., 1998; Hoffman, 2002; Hoffman and Halverson, 2008). The contact of the Rasthof with the underlying Chuos Formation is knife-sharp, with the diamictite overlain by dark gray mechanically laminated dolomite and dolomitic rhythmite.

\section{Methods}

At all localities, samples were collected at meter-scale from the lower Rasthof Formation for carbon isotope analysis. We collected hand samples for petrographic observation of microbial fabrics and analyses of carbon isotope composition of microfacies. Microfacies were analyzed to determine the source of carbonate ions during production and lithification of carbonate phases. Upon discovery of small circular features in light laminae of thickly laminated microbialaminite thin sections, we performed Raman spectroscopy (Vibrational Spectroscopy Lab, University of Massachusetts Amherst) to test whether these were composed of organic matter. These thin sections were also viewed under UV fluorescence (excitation at $370 / 40 \mathrm{~nm}$, emission at $425 \mathrm{~nm}$ ) using a Zeiss Axio Imager M1 microscope. Carbon isotope ratios were measured on a VG Optima gas source mass spectrometer and a Finnigan 


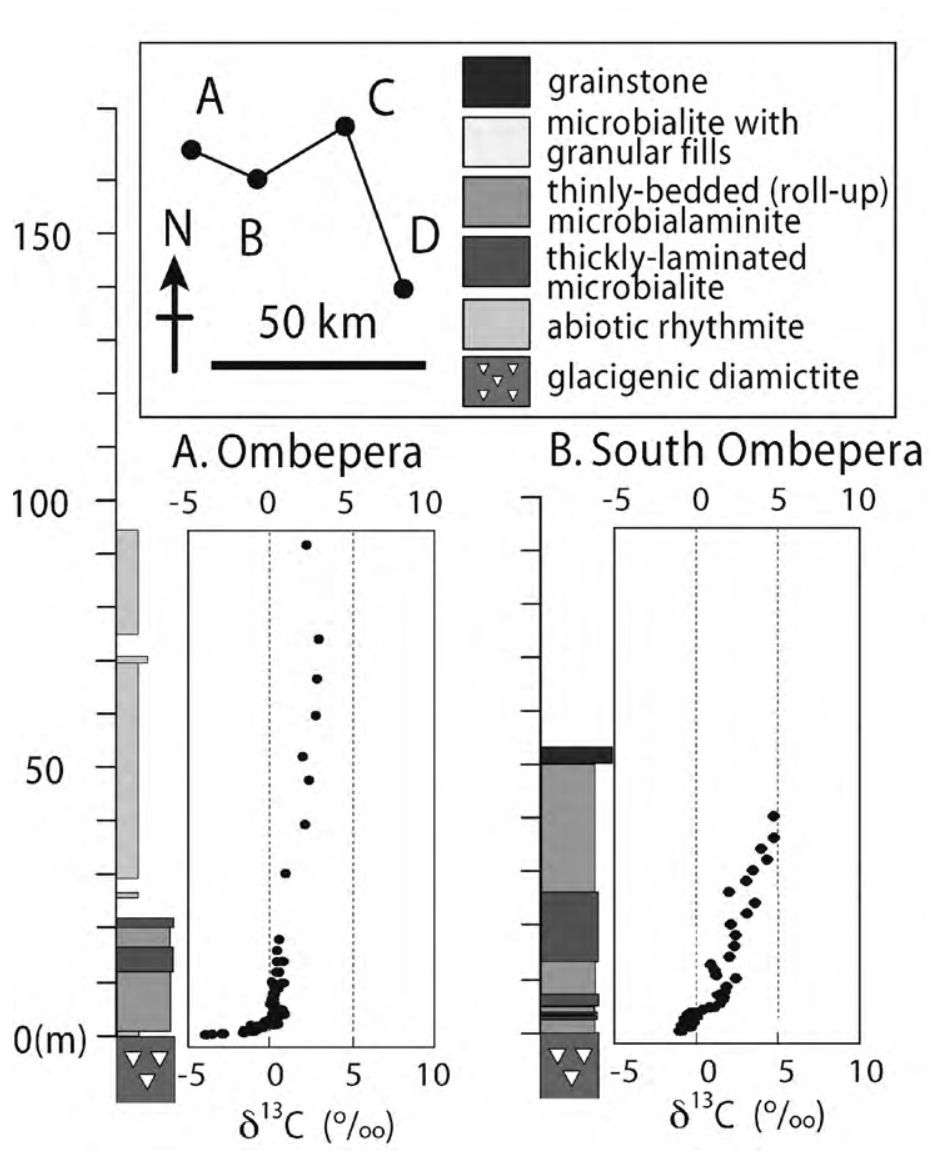

\section{Okaaru}

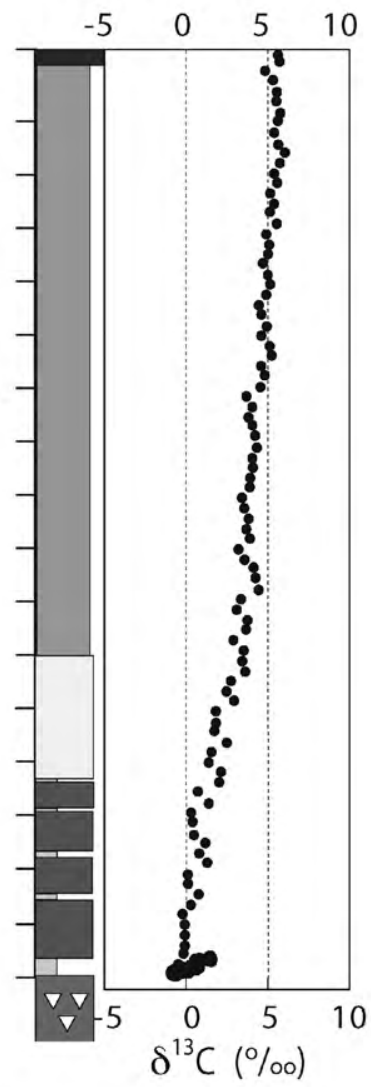

D. Ongongo

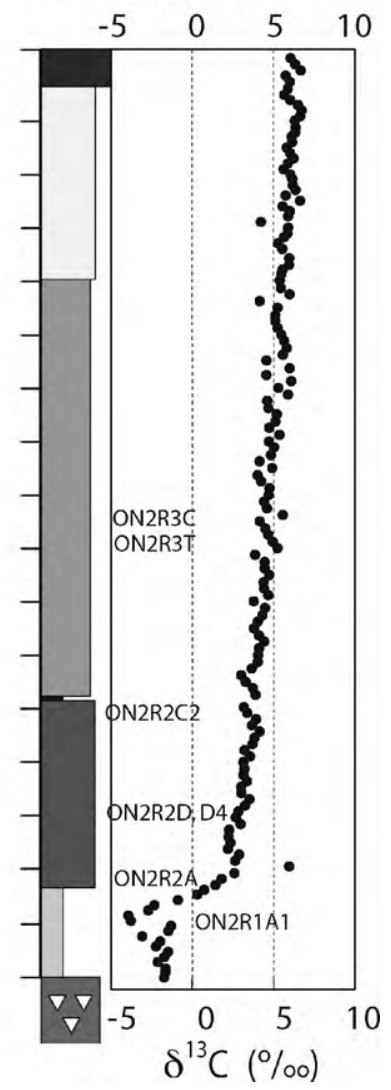

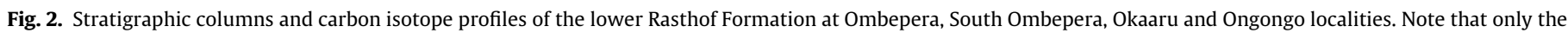
basal $\sim 170 \mathrm{~m}$ are shown at Ongongo and Okaaru.

Delta Plus XL ratio mass spectrometer, and values are reported relative to a PDB standard.

\section{Stratigraphy, geochemistry and analysis of microbial facies, the Rasthof Formation}

\subsection{Lithostratigraphy and carbon isotope stratigraphy}

To determine the origin of the microbial structures in the Rasthof Formation, we examined four exposures along a northwest transect (Fig. 1), located along a developing western margin (Hoffman and Halverson, 2008). At the most southeastern measured section, Ongongo, north of the Hoanib River valley (Fig. 1), the Rasthof Formation is $\sim 275$-m thick (Fig. 2). The lower Rasthof, from base to top, consists of $17 \mathrm{~m}$ of $\mathrm{cm}$-sized rhythmite beds of allodapic wackestones and laminites, $35 \mathrm{~m}$ of thickly laminated microbialaminite (with 1-4-mm thick laminae) capped by a m-thick cross-bedded siltstone, $79 \mathrm{~m}$ of thinly laminated microbialaminite (with sub-mm thick laminae and roll-up structures). Grainstone facies dominate the upper Rasthof. Both the thinly and thickly bedded microbialaminite facies contain carbonate clastic dikes (0.1-0.5 m wide) that cut across bedding and contain disrupted laminae and void cements. To date, we have not observed these dikes in any other facies.

At the Okaaru locality to the northwest (Fig. 1), the basal Rasthof Formation alternates between decimeter-thick beds of allodapic rhythmites with $5 \mathrm{~mm}$ to $1-\mathrm{cm}$ thick laminae and $1-2-\mathrm{m}$ thick beds of thickly laminated and broadly folded microbialaminite through $\sim 40 \mathrm{~m}$ of section (Fig. 2). The folded microbialaminite contains laminae that are truncated by dikes similar to those at Ongongo.
Up-section, the thickness of laminations decreases in a gradational fashion and roll-ups become prevalent at about $60 \mathrm{~m}$ from the base of the section. Roll-up structures are also associated with dikes that cut across stratigraphy and locally deform the horizontal lamination.

The lower Rasthof Formation is $\sim 50-\mathrm{m}$ thick at the South Ombepera locality (Figs. 1 and 2). The basal $10 \mathrm{~m}$ consists of alternating and interfingering thickly and thinly laminated microbialaminites but rhythmite is absent from the base of the section. Thickly laminated microbialaminite is folded into decimeter-sized upward-oriented domes and are commonly associated with clastic dikes filled with early marine cements. The thinly laminated microbial facies contains roll-up structures. The overlying $40 \mathrm{~m}$ of section is broadly similar to the underlying facies but contains more brecciated microbialaminite surrounded by void cements within dikes.

At Ombepera, located to the northwest of South Ombepera (Fig. 1), the lower Rasthof Formation is 21-m thick (Fig. 2). Approximately 2 -m thick mechanically bedded rhythmite is present at the base of the section, succeeded by thickly laminated microbialite interbedded with thinly bedded microbialaminite with roll-ups and an additional $\sim 70 \mathrm{~m}$ of graded grainstone beds and rhythmite that were assigned to the upper Rasthof Formation.

Carbon isotope profiles through the Rasthof Formation have been reported in several studies (Yoshioka et al., 2003; Hoffman and Halverson, 2008; Halverson et al., 2005), and all reproduce a strong signal starting near $-4 \%$ at the base and increasing smoothly to $+5 \%$. In an attempt to correlate the four stratigraphic sections in time and to determine the relative timing of microbial facies deposition during the transgression, we collected samples at high 
resolution for carbon and oxygen isotope analyses at the Ongongo, Okaaru, South Ombepera and Ombepera (Fig. 2). The $\delta^{13} \mathrm{C}$ values are light ( -2 to $-4 \%$ ) at the base of the Ongongo section and show a shift in the positive direction, with values reaching $+3 \%$, during the transition from mechanically laminated basal carbonates to the thick microbialaminite facies (Fig. 2). In contrast, light $\delta^{13} \mathrm{C}$ values ( -2 to $-4 \%$ ) are not preserved at the base of the Rasthof Formation at Okaaru. At the South Ombepera locality, the transition from light values $(\sim-1 \%$ ) at the base of the section to $+5 \%$ o up-section occurs over a much smaller stratigraphic thickness than at Ongongo or Okaaru. The Ombepera section differs from the South Ombepera section in a few important ways: the transition from light $\delta^{13} \mathrm{C}$ values $(-4 \%)$ to heavier values is well preserved, but carbon isotope values do not reach the $+5 \%$ o within the measured section as at South Ombepera and the other localities.

\subsection{Analysis of microbial facies in the Rasthof Formation}

\subsubsection{Thickly laminated microbialaminites}

The thickly laminated microbialaminite is most distinct from the thinly laminated roll-up facies at Ongongo; however, examination of the microbialaminites at other localities reveals that
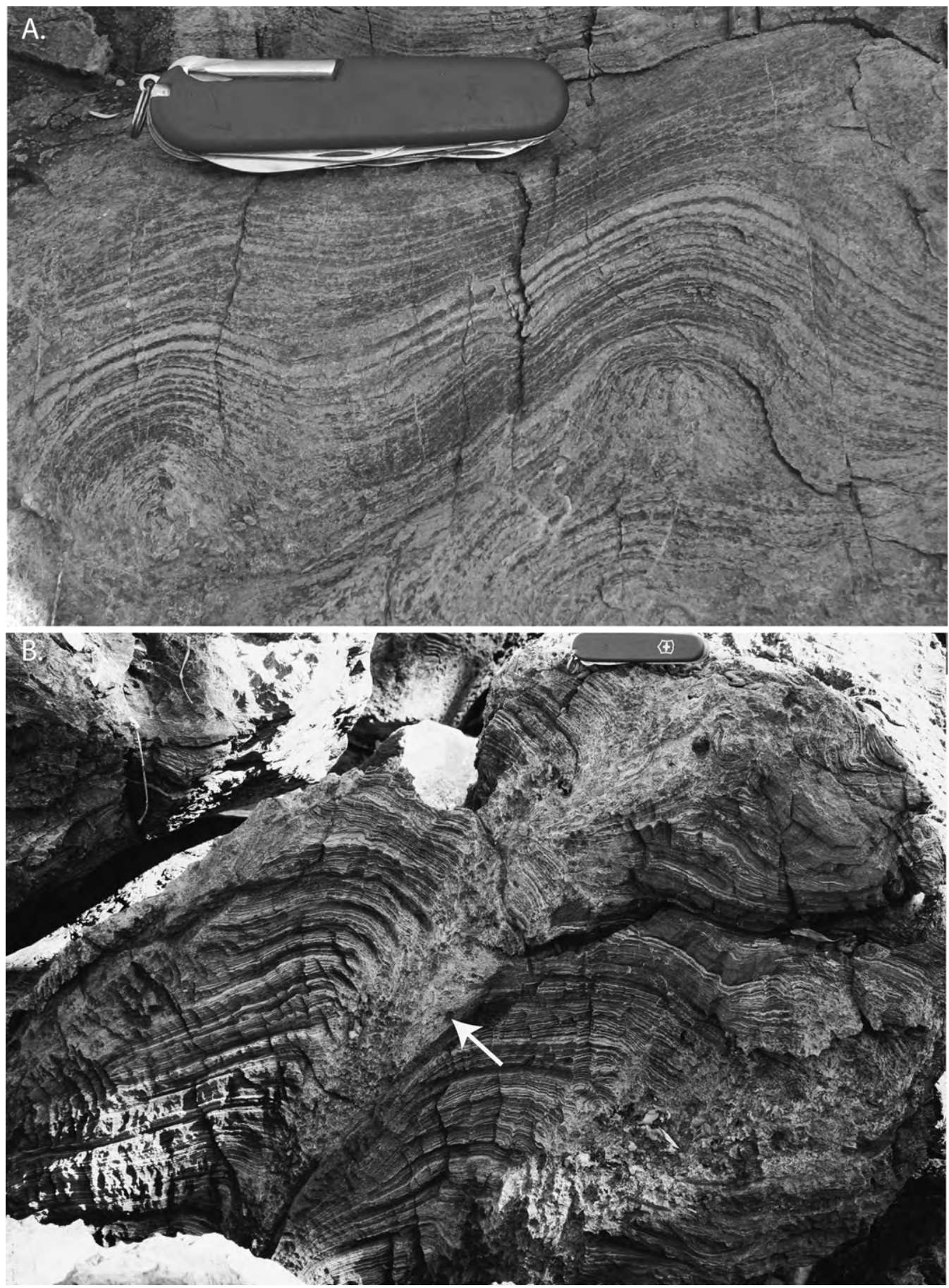

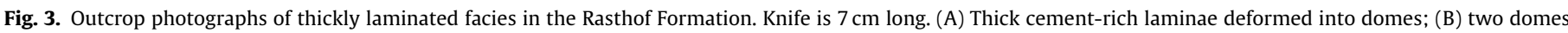
with a dike between them (arrow) illustrating the soft sediment deformation that occurs on the margin of dikes. 

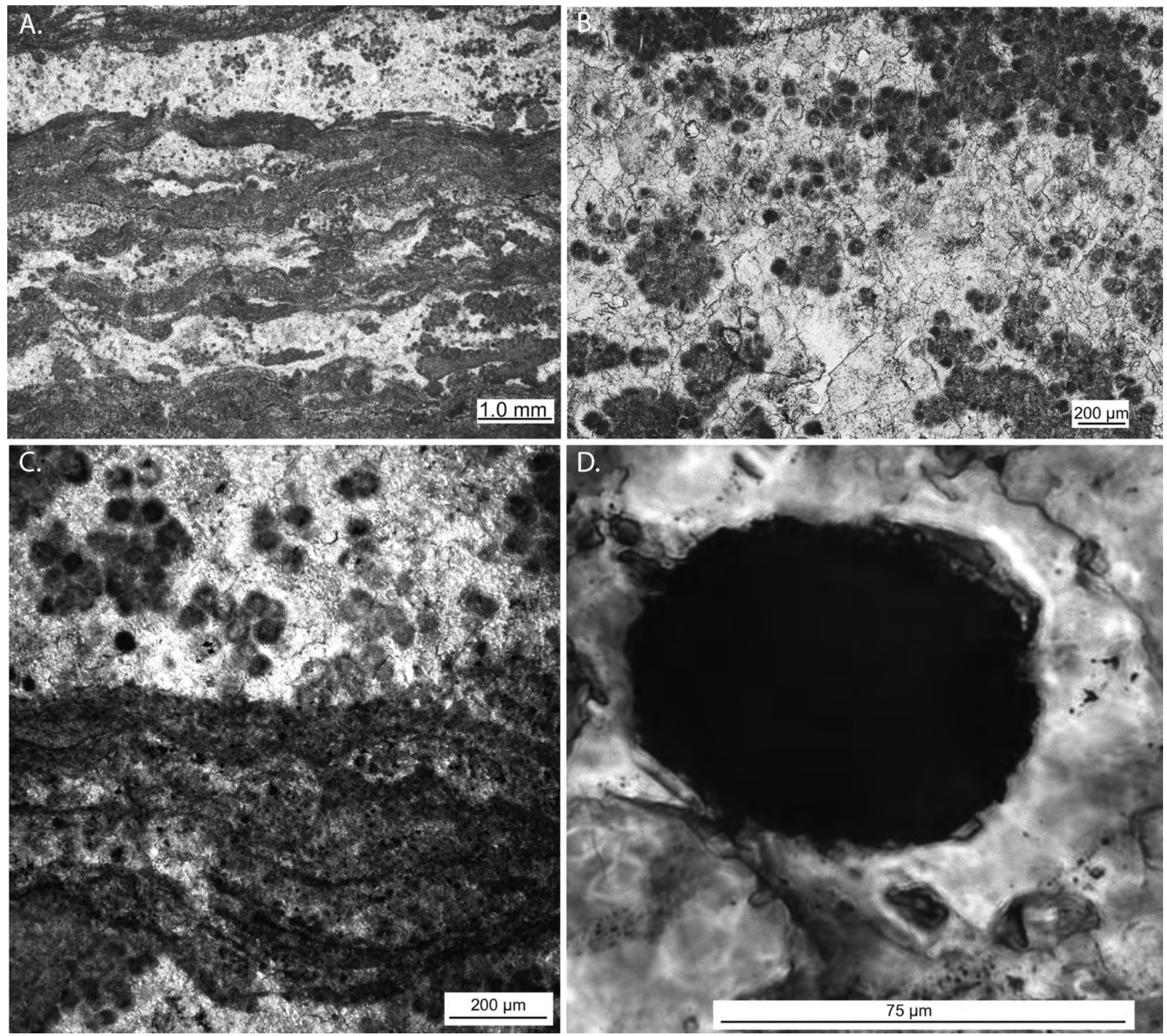

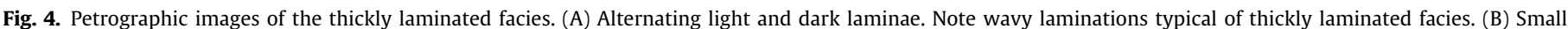

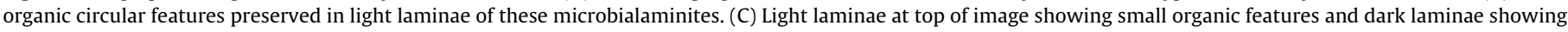
$10 \mu \mathrm{m}$-thick microbial laminations. (D) Close-up of an organic-rich circular feature in the light lamina.

lamination thickness can vary within a meter of stratigraphy and occasionally exhibit an interfingering relationship. The thickly laminated microbialaminite facies, characterized by $1-4-\mathrm{mm}$ thick alternating light and dark laminae (Fig. 3) does not exhibit stratal organization, zonation, or evidence of shoaling or exposure. The laminae are sometimes folded into typically $10-50$-cm thick folds that are preserved as laterally linked and individual dome-like features (Fig. 3). Carbonate clastic dikes (0.1-0.5 m wide) and veins (1-10 cm wide) cut across bedding throughout this thickly laminated microbialaminite facies (Fig. 3B) and are commonly filled with $\mathrm{cm}$-sized botryoidal and bladed cements and dark deformed and folded laminae that were displaced into dikes during their opening. The dikes and cement-filled voids terminate abruptly at various horizons and at varying angles with respect to bedding.

Petrographic examination of thickly laminated microbialites reveals that the crystals in the dark and light laminae, respectively, differ both in size and organic content (Fig. 4). Light layers contain coarse, clear equant crystals of dolomite (100-200- $\mu \mathrm{m}$ diameter) whereas the dark layers contain $<20 \mu \mathrm{m}$ dolomite crystals (Fig. 4A-C). Brown circular structures $\sim 70 \mu \mathrm{m}$ in diameter, often containing discernible dark walls are preserved either individually in the centers of the large, clear dolomite crystals or in clusters (Fig. 4B-D). Raman spectroscopy confirms that these structures contain organic matter (Fig. 5). The light laminae containing individual organic-rich circular structures are preserved next to dark laminae that contain many $\sim 10-\mu \mathrm{m}$ thick organic-rich laminae (see Fig. 4B). These thin laminae, presumably formed by prostrate filamentous microbes, can laterally grade into grumeleuse microstructure (sensu Turner et al., 2000) but none of the individual filaments were preserved. Finely disseminated cubic sulfide minerals are present only in the dark laminae, suggesting that sulfate reduction occurred preferentially within the dark laminae.

To constrain sources of alkalinity for various microfacies, we analyzed and compared the $\delta^{13} C_{\text {carb }}$ of individual void cement 

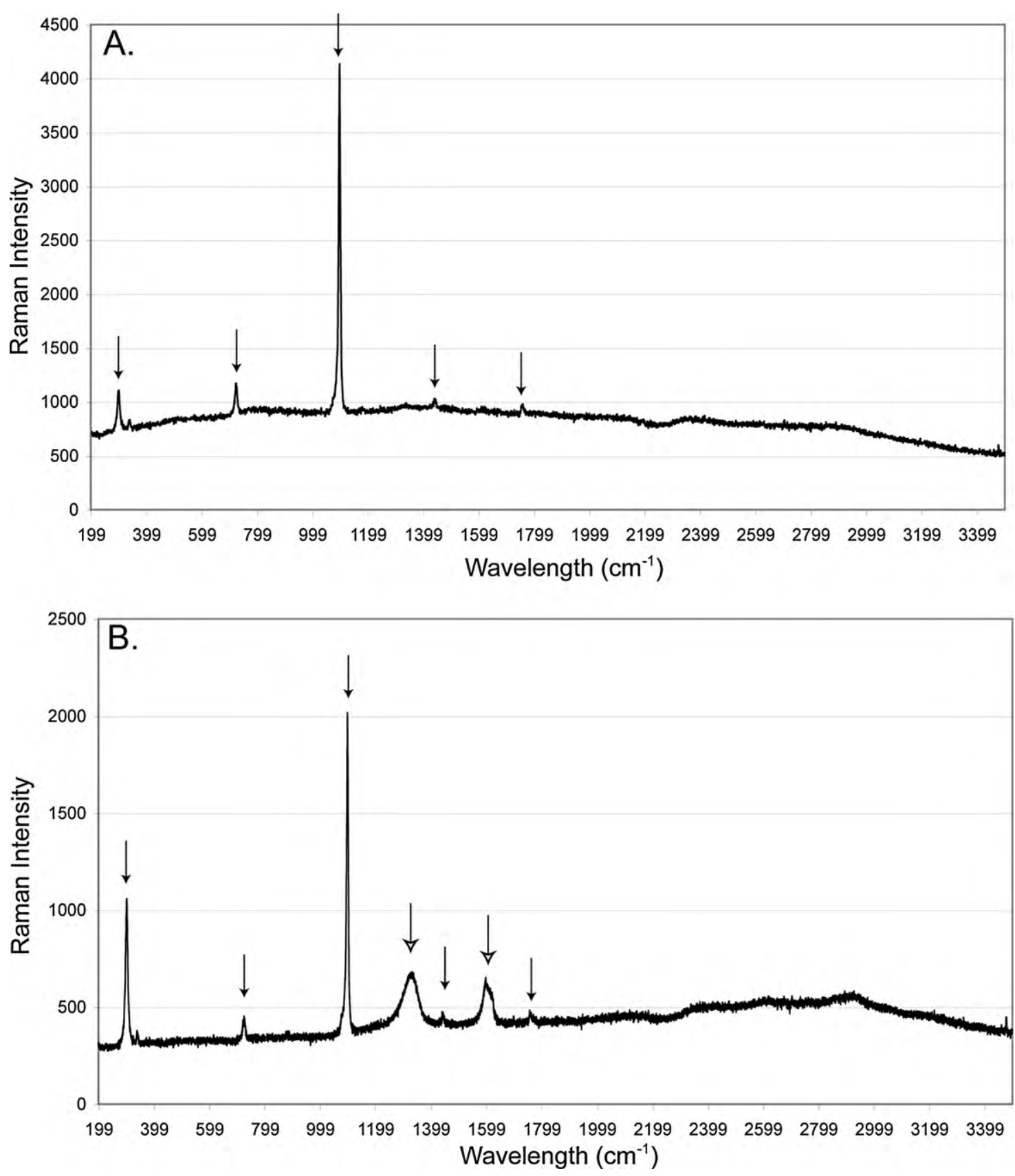

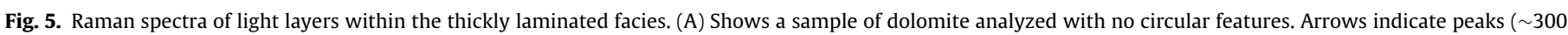

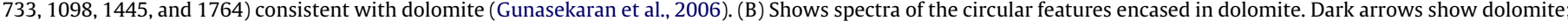
white arrowheads indicate peaks consistent with bulk organic matter (peaks at 1340 and 1600) (e.g. Pasteris and Wopenka, 2003).

and laminae from thickly laminated facies to associated micrite (Table 1$)$. In general, $\delta^{13} \mathrm{C}$ values of both the individual laminae and cements resemble bulk carbonate $\delta^{13} \mathrm{C}$ values and reflect their respective stratigraphic position during the increase in carbon isotope values. For example, light and dark laminae from samples collected at the base of the thickly laminated facies showed values of -1.69 and $-1.68 \%$, respectively, whereas light and dark laminae from the top of the section recorded $\delta^{13} \mathrm{C}$ values of 3.71 and $3.52 \%$, respectively (see Fig. 2). Void cements also resemble associated carbonate to within $\sim 0.2 \%$ 。 (Table 1).

\subsubsection{Thinly laminated microbialaminite and roll-up structures}

The thinly laminated microbialaminite can be easily distinguished from associated strata because of its dark gray color, sub-mm size thickness of laminae, and occurrence of roll-up structures (Fig. 6). The dark gray color originates from the presence of typically $\sim 0.5-\mathrm{mm}$ thick gray laminae that are thicker than the lighter gray laminae (typically $\sim 0.2-\mathrm{mm}$ thick). Roll-up structures consist of 2-20-sub-mm thick layers of laminated dolomite or dolomitic limestone that have folded back or "rolled up" on themselves (Fig. 6A-C) and often occur in close proximity to dikes (Fig. 6A, C and D). They can occur as individual folds in an otherwise undisturbed bed or as a series of adjacent folds (Fig. 6B). Roll-up structures are typically less than $10-\mathrm{cm}$ thick and are present in all examined Rasthof exposures on the western Otavi margin that contain the thinly laminated microbialaminite facies. What appears as a single roll-up in outcrop, consisting of a few folded layers of microbialaminite, can often become a series of several smaller rollups. High-resolution images of a single roll-up structure captured 

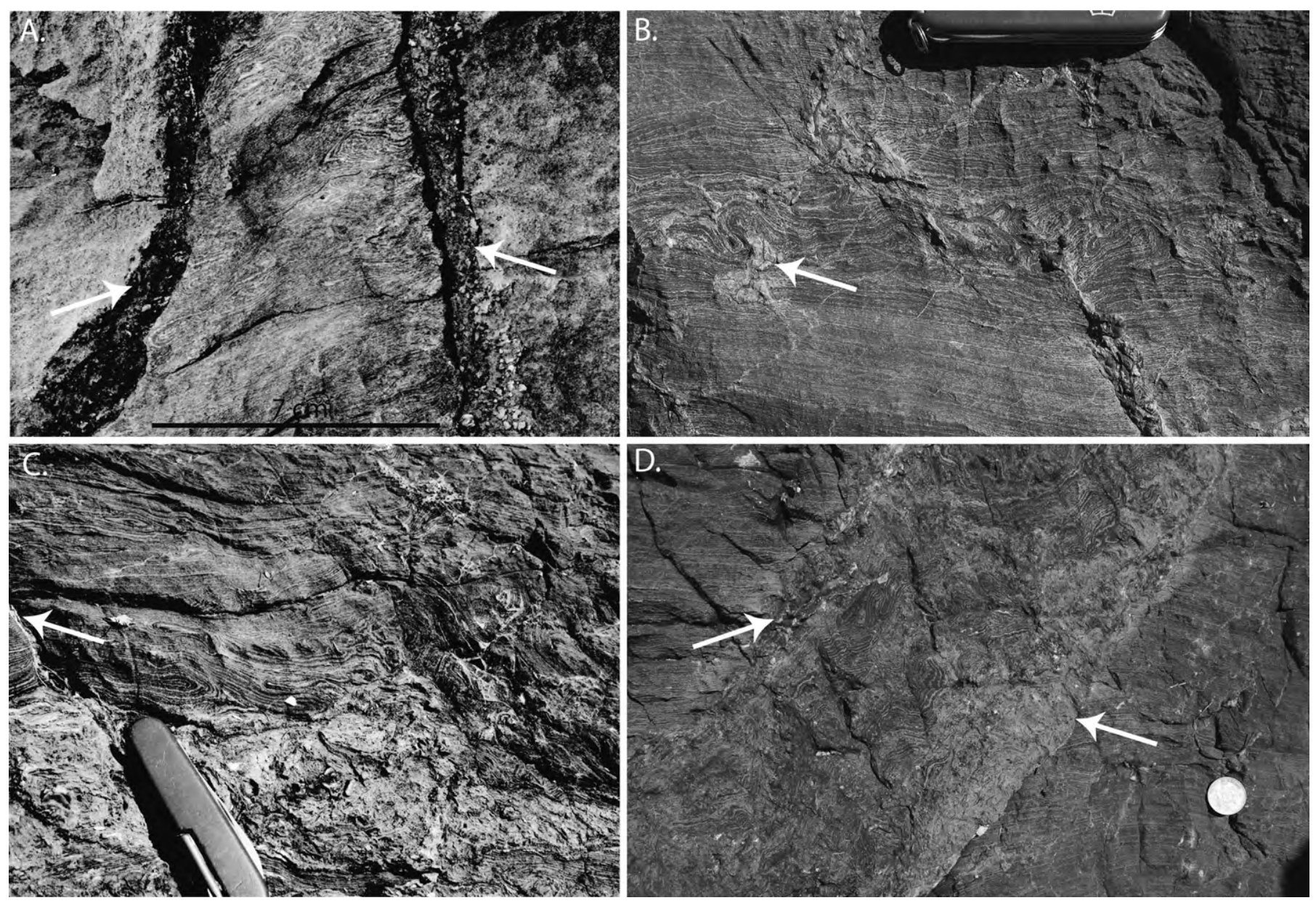

Fig. 6. Photographs of roll-up structures and large dikes preserved in microbialaminite facies of the Rasthof Formation. Knife is $7 \mathrm{~cm}$. (A) Two small dikes that cut through stratigraphy (arrows) and resultant roll-up structures preserved between them, Okaaru locality. (B) Multiple roll-up structures in one horizon. Void cements are associated with roll-ups on the left (arrow), Ongongo locality. (C) Laterally emplaced dike filled with void cements and small branch of dike cutting through stratigraphy (arrow). Roll-up structures form around the margins of dikes, South Ombepera locality. (D) Large dike (edges indicated by arrows) cutting across bedding in the microbialaminite facies, Ongongo locality.

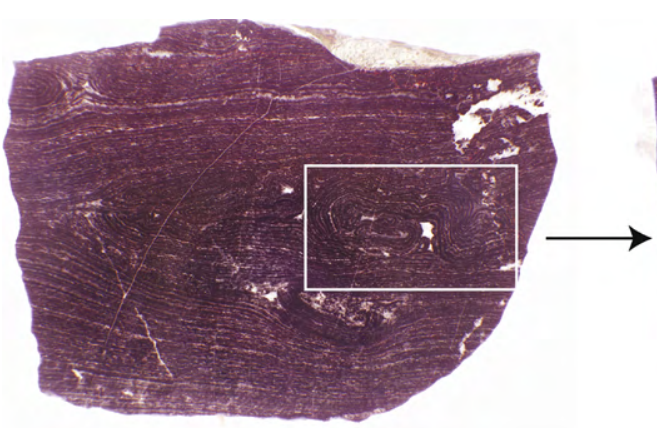

$71.17 \mathrm{~mm}$

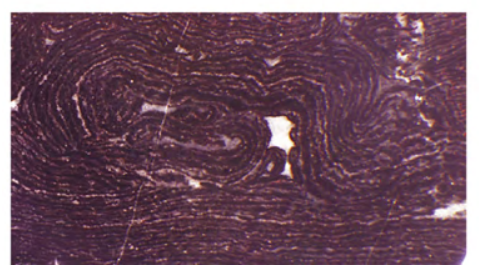

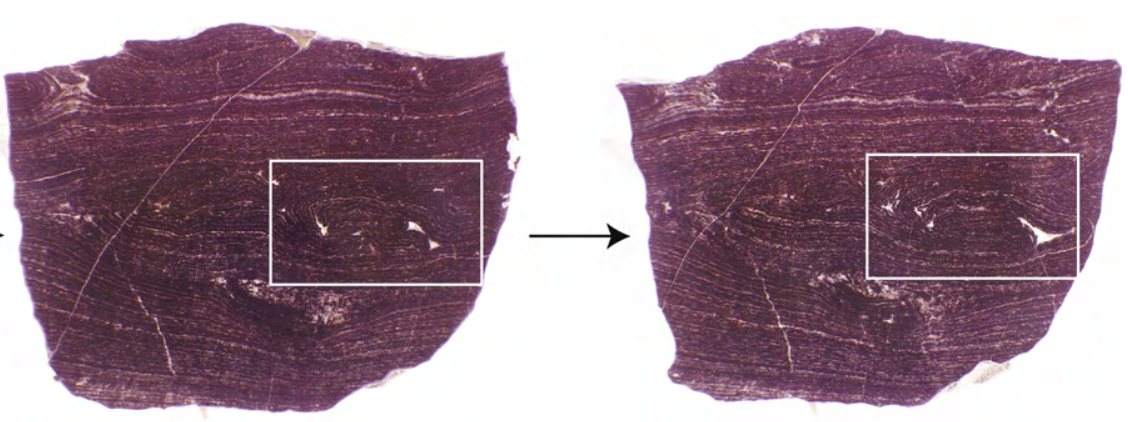

$65.61 \mathrm{~mm}$

$60.19 \mathrm{~mm}$
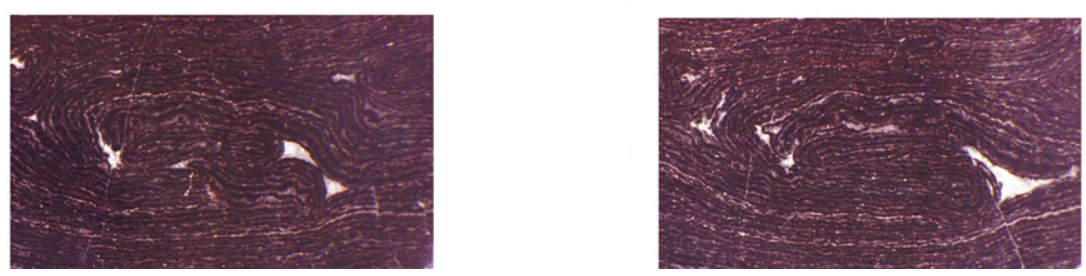

Fig. 7. Series of serial sections of a single roll-up structure. Thickness of the sample is shown at the bottom. Note how the size and shape of the roll-up changes through a few cm's laterally. 
Table 1

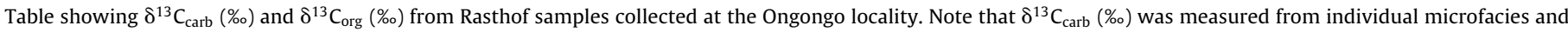

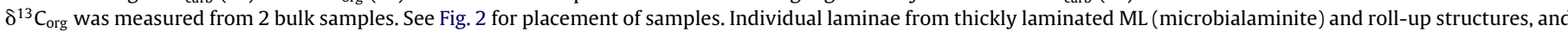
individually drilled void cements show little $\delta^{13} C_{\text {carb }}$ isotopic difference from bulk carbonate from the same stratigraphic horizon.

\begin{tabular}{|c|c|c|c|c|}
\hline Sample ID & Description & $\delta^{13} C_{\text {carb }}(\%)$ & $\delta^{18} \mathrm{O}$ & $\delta^{13} C_{\text {org }}(\%)$ \\
\hline \multicolumn{5}{|l|}{ Sample 1} \\
\hline ON2R1A1-A & Rhythmite, dark lamina & -1.68 & -6.47 & \\
\hline ON2R1A1-B & Rhythmite, light lamina & -1.69 & -7.29 & \\
\hline \multicolumn{5}{|l|}{ Sample 2} \\
\hline ON2R2A-A & Thickly laminated ML, light lamina & 1.16 & -3.84 & $>45 \mu \mathrm{m}:-23 \pm 0.4$ \\
\hline ON2R2A-B & Thickly laminated ML, dark lamina & 0.43 & -2.13 & $<45 \mu \mathrm{m}:-22 \pm 0.7$ \\
\hline \multicolumn{5}{|l|}{ Sample 3} \\
\hline ON2R2C2-A & Thickly laminated ML, light lamina & 3.71 & -2.64 & \\
\hline ON2R2C2-B & Thickly laminated ML, dark lamina & 3.52 & -1.44 & \\
\hline \multicolumn{5}{|l|}{ Sample 4} \\
\hline ON2R2D-B & Thickly laminated ML, micrite & 2.42 & -3.21 & \\
\hline ON2R2D-A & Thickly laminated ML, void cements & 2.25 & -3.48 & \\
\hline \multicolumn{5}{|l|}{ Sample 5} \\
\hline ON2R2D4-A & Thickly laminated ML, micrite & 2.59 & -2.23 & \\
\hline ON2R2D4-B & Thickly laminated ML, micrite & 2.84 & -3.27 & \\
\hline ON2R2D4-C & Thickly laminated ML void cements & 2.40 & -3.75 & \\
\hline \multicolumn{5}{|l|}{ Sample 6} \\
\hline ON2R3C & Roll-up lamina & 4.31 & -3.62 & $>45 \mu \mathrm{m}:-18 \pm 3$ \\
\hline ON2R3C-B1 & Roll-up lamina & 4.45 & -3.37 & \\
\hline \multicolumn{5}{|l|}{ Sample 7} \\
\hline ON2R3T-3D & Roll-up from talus; dark lamina & 5.22 & -2.12 & \\
\hline ON2R3T-3C & Roll-up from talus; light lamina & 5.24 & -1.75 & \\
\hline ON2R3T-3E & Roll-up from talus; void cement & 4.98 & -1.96 & \\
\hline ON2R3T-3A & Roll-up from talus; dark lamina & 5.00 & -2.48 & \\
\hline
\end{tabular}

during serial grinding confirm that roll-up structures can vary in shape and size, even through only a $\mathrm{cm}$ of lateral space within a sample (Fig. 7). Individual laminae within the roll-up structures also occasionally exhibit truncation or breakage. Within a single bed, roll-up structures can be flanked on either side by flat, undisturbed laminae. Similarly, microbialaminite below and above the roll-up structures often remains completely undeformed.

Syndepositional dikes and smaller veins are present in the rollup facies (see Fig. 6D) and conspicuously absent from other facies such as rhythmites and grainstones. The dikes contain void cement, occasional clasts of microbialaminite, and undulating microbial mats that may have collapsed during the formation of dikes. Undisturbed microbialaminite layers overlie the disturbed void-filled areas. As in the thickly laminated facies, voids contain cements.

In thin section, roll-up structures consist of $10-100-\mu \mathrm{m}$ thick individual dark laminae (Fig. 8A, C) and are often associated with void cements (Fig. 8B). Void cements are dolomitic or silicified and exhibit bladed and equant morphologies in thin section (Fig. 8B). UV fluorescence and petrographic images show that darker layers contain abundant organic matter and pyrite, whereas more coarsely crystalline dolomite $(20-50 \mu \mathrm{m})$ and some organic matter form the somewhat lighter laminae. Brownish-red microfossils with organic walls and oval cross-sections are present in both dark and light layers (Fig. 8D).

To constrain possible sources of alkalinity for lithification within microbial facies, we measured the isotopic composition of $\delta^{13} C_{c a r b}$ in microbial micrite and void cement from two different hand samples of roll-ups and found few differences in isotopic composition between the microfacies (Table 1 ). Namely, all $\delta^{13} \mathrm{C}$ values of micrite and void cements in roll-up structures were between +4.3 and $+5.2 \%$, which resemble bulk carbonate results for the thinly bedded microbialaminite facies (see Fig. 2, Table 1). Organic matter from microbialaminites from the Rasthof Formation has a $\delta^{13} C_{\text {org value of }}-18$ to $-23 \%$ (Table 1, Kaufman et al., 2003), and is depleted by, at most, $\sim 24$ per mil relative to the surrounding carbonate matrix (Table 1 ).

\section{Discussion}

\subsection{Interpretation of carbon isotope profiles and lithostratigraphy}

Chemostratigraphy and lithostratigraphy of the four examined sections provide insights into environments and depositional processes in the aftermath of glaciation. Near Ombepera, both the upper Rasthof Formation and the overlying Gruis and Ombaatjie Formations become dominated by shale to the west, demonstrating a deepening direction to the west during deposition of the overlying strata. Although the microbialaminite facies of the lower Rasthof Formation also thin to the west, no systematic onlap from the west is apparent from either the lithostratigraphy or the carbon isotope chemostratigraphy (Fig. 2). That is, both the negative carbon isotope values and the basal allodapic carbonates are absent. These facies patterns can be reconciled in part by the recognition that the southern margin of the Congo Craton was active during deposition of the Rasthof Formation (Hoffman and Halverson, 2008), and that significant topography was likely present on the margin in the aftermath of the Sturtian glaciation, both as a result of active tectonism and sub-glacial erosion. The basal graded rhythmite beds are laterally discontinuous, filling post-glacial topography. We interpret differences between carbon isotope profiles from different sections as a reflection of lateral differences in accumulation rates and the timing of onlap. For example, the relatively sharp rise from -3 to $+3 \%$ in the Ongongo locality, and the influx of a allodapic material $50 \mathrm{~m}$ from the base of the section, may be related to a rotating rift shoulder, rising to the south and sinking to the north (Hoffman and Halverson, 2008).

Stratigraphic analysis of sections on the western margin also reveals that many of the lower Rasthof Formation facies formed below storm wave base because there is no evidence for wave activity in the rhythmites, thickly laminated microbialaminite or roll-up microbialaminite. However, because the stacking pattern of these facies differs from locality to locality, it is not evident which 



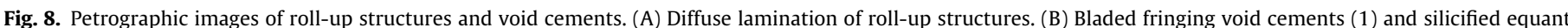

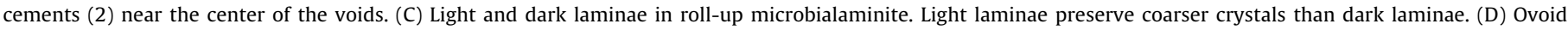
microfossils commonly preserved in roll-up facies with well-preserved walls.

facies represents the deepest water deposits. Rhythmites, which are characteristic of the basal Rasthof Formation at Ongongo and are often interpreted as the deepest water facies, are absent at the South Ombepera locality but are present in the upper Rasthof at the Ombepera locality. Rhythmites therefore do not characterize basal Rasthof deposition at all localities. It is possible that maximum flooding was not achieved at the base of the Rasthof Formation, but rather, that the lower Rasthof Formation records transgression with maximum flooding occurring up-section. Alternatively, sedimentation could have postdated transgression, and variations in basal facies simply reflect the complex filling of post-glacial topography. Future analysis of sections to the north of these may provide a way to resolve the nature of transgression along this margin during glacial aftermath.

Carbon isotope analyses of the lower Rasthof Formation at the four localities show lateral variations, particularly at the base of the sections (see Fig. 2). At Ongongo, the shift from -4.6 to $+3 \%$ occurs stratigraphically above the base of the section. The only other locality where the Rasthof Formation exhibits values near $-5 \%$ onear the base of the section is Ombepera. This suggests that the variable rates of post-glacial carbonate accumulation likely resulted in variations in the basal carbon isotopes profiles as well as in lateral facies differences. The carbon isotope profiles of all of the localities gradually climb to values of $+3 \%$ o to $+5 \%$ o in the later stages of transgression or highstand.

\subsection{Formation of microbial facies and structures in the Rasthof Formation}

The thickly laminated microbialaminite facies in the Rasthof Formation can occur at a different stratigraphic horizon than the thinly bedded microbialaminite, as at Ongongo, or as interbedded facies at Okaaru, South Ombepera, and Ombepera. This relationship suggests that these two facies formed in close association with each other on the seafloor during Rasthof time, with the lamination size reflecting differences in accumulation and/or lithification rates. The thickly bedded microbialaminites, which exhibit broad dome-shaped folds contain thicker light laminae. We attribute the formation of these thick light laminae to episodes when carbonate cementation outpaced the growth of microbial mats. Most easily interpreted as remnants of benthic microbial mats that were fossilized by in situ nucleation of originally fine-grained carbonate, sequences of $\sim 10$ - $\mu \mathrm{m}$ thin organic-rich laminae represent episodes of early micritization but incomplete lithification. Larger, pyrite poor dolomite crystals are (Fig. 4A, C and D), in turn, consistent with episodes when biomass accumulated more slowly. Some of the less distinct aggregates of round organic-rich structures in the light layers, or grumeleuse structure, may be interpreted as a taphonomic variation of the same communities that built finely laminated mats, much like the fabrics in some Early Neoproterozoic reefs (Turner et al., 2000). However, the very sharp contact between 
some of the best preserved thin dark laminae and large dolomite crystals encasing individual walled, circular structures (Fig. 4) and the apparent rarity of these structures in the dark laminae suggests that many of these organic-rich structures cannot be interpreted as simple taphonomic derivatives of the same biota that formed dark laminae.

In roll-up facies, the light laminae are an order of magnitude thinner than those in the more cement-rich thickly laminated microbialites. This suggests that the mats were soft and cohesive, with partially micritized dark organic laminae at the time of the deformation. These laminae did not become fully lithified until they were centimeters below the sediment water interface. In contrast, the presence of numerous thick light laminae with large clear dolomite crystals in the thickly laminated and broadly deformed microbialaminites suggests a relatively higher extent of lithification in these mats prior to deformation.

Evidence for continued biological activity during the formation of the Rasthof Formation is thus preserved in the morphology of microbialaminites, their chemical composition and the associated microfossil record. To the first order, the biota associated with these microbialites did not depend on the degradation of hydrocarbons, as suggested by the absence of the extremely depleted carbon isotopic signatures characteristic of microbial communities fueled by methane (Table 1; Kaufman et al., 2003) from the organic matter in either thickly or thinly laminated microbialites. Some organisms responsible for the degradation of organic matter in dark microbialaminites produced finely disseminated pyrite. Others were likely preserved as individual organic-rich microfossils (see Fig. 8D). Although preliminary geochemical analysis of carbonate in the Rasthof Formation is consistent with low sulfate levels at the time (Hurtgen et al., 2002), the restriction of pyrite to dark laminae is consistent with its origin as a by-product of sulfate reduction associated with the degradation of organic matter. The uniformity of $\delta^{13} C_{\text {carb }}$ across different fabrics (Table 1) also indicates that the cementation relied on inorganic carbon that was by and large not derived by the remineralization of organic matter within the microbialaminites (e.g. Stephens and Sumner, 2002).

The patchy distribution of the roll-up structures suggests that deformation occurred locally and was most likely due to occasional disruption of the only partially lithified sediment by fluid-flow. Individual roll-ups are commonly less than $10-\mathrm{cm}$ thick, and rollup horizons are not traceable over distances $>1 \mathrm{~m}$. Mechanisms that deformed soft microbially bound sediments in the Rasthof Formation are thus inconsistent with structures formed from slumping of sediment on a slope. Moreover, were these features related to slumping on a slope, roll-up structures should show preferential lateral orientation in outcrop, but field observations suggest this is not the case (see Fig. 6A-C) (Hoffman and Halverson, 2008).

The absence of bedforms at all localities where microbialaminites in the Rasthof Formation were examined implies that waves, storms and currents did not play a large role in the deformation of microbialaminite facies in this unit. It is possible that the absence of non-cohesive granular sediment may be responsible for the lack of bedforms, but even exhumed clasts of microbial mats or scour marks (Pruss et al., 2004), common features in stormy microbially dominated depositional settings, are lacking. The patchy distribution of roll-up structures within a single horizon (roll-up horizons typically cannot be traced for more than a meter), the complexity of a single roll-up structure through only a few centimeters of lateral space (Fig. 7), and the absence of evidence for current alignment argue against bottom currents or waves as a dominant mechanism of deformation.

The potentially most informative feature found in the two microbialaminite facies is the common presence of abundant, and sometimes laterally extensive, dikes and voids (Fig. 6D). The pres- ence of displaced cohesive, but initially unlithified microbial mats within and on the flanks of dikes, and the similarity between the $\delta^{13} C_{\text {carb }}$ composition of void cements and micrite (Table 1) suggest that the accretion of dark layers, light layers and void cements, was syndepositional to the soft sediment deformation (Fig. 9). The dikes and voids appear to lack a preferred orientation, but instead occur perpendicular, parallel, and oblique to bedding. Further work is required to systematically assess the orientations to determine their relationship to extensional structures on the margin. The formation of bladed void-filling cements and the presence of folded microbialaminite layers and fragments in the dikes supports their origin as conduits for either water or gas escape. Although methane is a common gas released from modern deep sediments, there is little evidence for methane release in the Rasthof carbonates. For examples, the cements are not isotopically depleted relative to the surrounding microbialites (e.g., Campbell, 2006), nor is the isotopic composition of carbon in the organic matter from the microbialaminites depleted with respect to the surrounding carbonate by more than $\sim 23$ per mil, as would be expected for a methane-fueled biota (e.g. Stakes et al., 1999). Water released during the compaction and lithification of carbonates is thus the most likely candidate fluid that deformed laminated microbialites in the Rasthof Formation.

We interpret the difference in deformation style in the thickly and thinly laminated microbialaminite as a consequence of differing rheological responses to the formation of dikes and propose a model for the deformation of these soft sediments (Fig. 9). Fluids released from below the sediment-water interface along planes of weakness, facilitated by areas of unlithified or partially lithified sediment, were ultimately released into the overlying water column. As a consequence, cement-rich thickly laminated microbialaminite facies deformed into broad folds during dike formation. In contrast, the emplacement of dikes within the organic-rich but cement-poor thinly bedded microbialaminite resulted in roll-up structures. Tectonic activity may have facilitated the formation of these dikes and the consequent soft sediment deformation by initiating fluid escape during earthquakes along the actively rifting margin.

\subsection{Other occurrences of contorted microbialites}

Although rare in the geological past, roll-up structures and other contorted microbialites, are not unique to the Rasthof Formation; they are more commonly found in shallow water settings where microbialites can be deformed by waves, currents and desiccation (Schieber et al., 2007). An example of such microbialites is preserved in the Neoproterozoic Beck Spring Formation exposed in the Death Valley region of eastern California, where thickly laminated contorted microbialites (Tucker, 1983) appear to have developed above wave base. Apart from the Sturtian occurrences (e.g. Arctic Alaska, Macdonald et al., 2009b; Mexico, Corsetti et al., 2007; Congo Craton of northern Namibia, Hoffman and Halverson, 2008; and the Kalahari Craton of southern Namibia) similar examples of roll-up structures from deep-water environments were described in the Archean deposits of western Australia and South Africa (Sumner, 1997; Simonson and Carney, 1999; Schroeder et al., 2009), where they are interpreted as formerly cohesive microbial mats that were deformed by an unspecified mechanism. The formation of contorted Rasthof microbialaminites below wave base, the structure of the roll-ups, and the proximity of soft sediment deformation to dikes suggests that these structures formed as a result of local deformation due to the formation of dikes during fluid escape (see Fig. 9). It is possible that fluid escape structures also played a role in the formation of contorted microbialites at other, earlier geological intervals, but further work is required to determine if this mechanism applies generally or is unique to the Rasthof Formation. 
A.
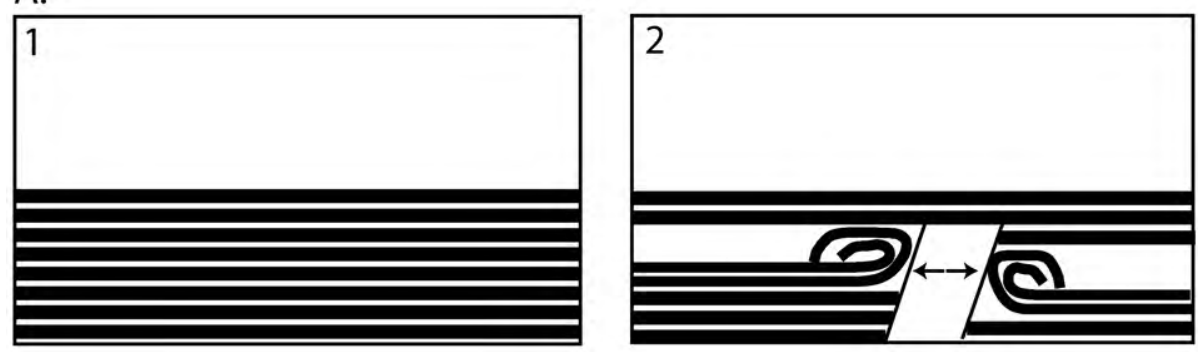

B.
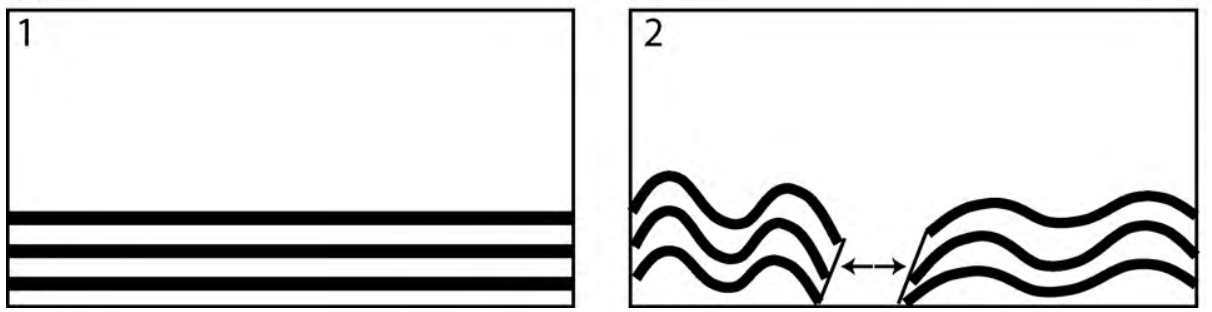

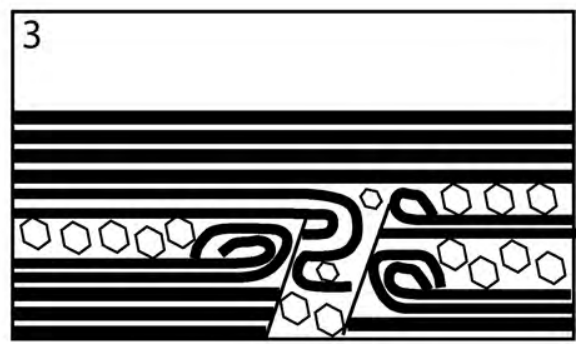

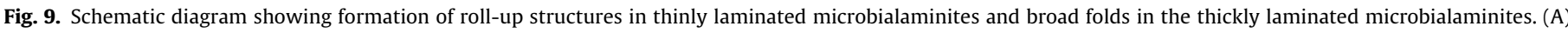

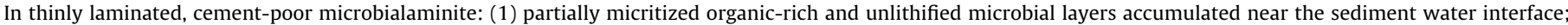

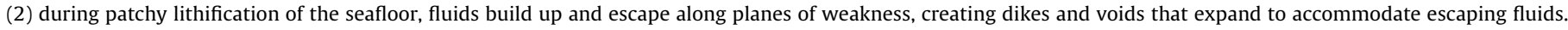

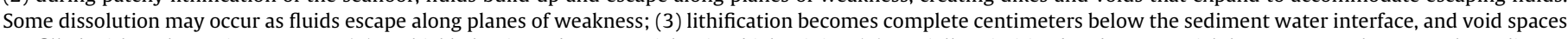

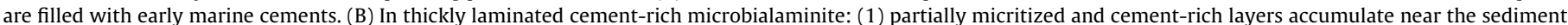

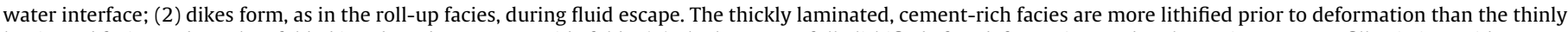
laminated facies and are thus folded into broad 0.1-0.5-m wide folds; (3) The layers are fully lithified after deformation, and early marine cements fill existing voids.

\section{Conclusions}

The microbialite facies in the lower Rasthof Formation are indicative of a microbial deep-water ecosystem that established itself in the aftermath of global glaciation. Both types of microbialaminites bear evidence of cohesive microbial mats that were disrupted by syndepositional formation of dikes and voids via dewatering. These unusual and distinct microbial structures in the Sturtian cap carbonate demonstrate that microbial communities thrived in the aftermath of global glaciation.

\section{Acknowledgements}

SP would like to acknowledge the invaluable field assistance of Clara Blättler and Sasha Breus, lab research and assistance by Katie Castagno, Lilly Dalton, and Jessica Weigand, the geochemistry lab of Stephen Burns and Shaw Ling Hsu's Raman spectroscopy lab at the University of Massachusetts at Amherst for analysis of Rasthof samples, and Bosiljka Glumac and the Smith College Geosciences department for assistance. TB would like to thank MS Sim. Field work in Namibia was supported by U.S. National Science Foundation (Geobiology and Environmental Geochemistry Program) Award EAR-0417422 (to PFH), (Sedimentary Geology and Paleobiology) Award EAR-0843358 (to TB and SP), Smith College, and Harvard University Center for the Environment (to $\mathrm{CB}$ ).

\section{References}

Allen, P.A., Hoffman, P.F., 2005. Extreme winds and waves in the aftermath of a Neoproterozoic glaciation. Nature 433, 123-127.

Campbell, K.A., 2006. Hydrocarbon seep and hydrothermal vent paleoenvironments and paleontology: past developments and future research directions. Palaeogeography, Palaeoclimatology, Palaeoecology 232, 362-407.

Cloud, P.E., Wright, L.A., Williams, E.G., Diehl, P., Walter, M.R., 1974. Giant stromatolites and associated vertical tubes from the Upper Proterozoic Noonday Dolomite, Death Valley Region, eastern California. Bulletin of the Geological Society of America 85, 1869-1882.

Corsetti, F.A., Grotzinger, J.P., 2005. Origin and significance of tube structures in Neoproterozoic post-glacial cap carbonates; example from Noonday Dolomite, Death Valley, United States. Palaios 20 (4), 348-362.
Corsetti, F.A., Stewart, J.H., Hagadorn, J.W., 2007. Neoproterozoic diamictite-cap carbonate succession and d13C chemostratigraphy from eastern Sonora, Mexico. Chemical Geology 237, 129-142.

Evans, D.A.D., 2000. Stratigraphic, geochronological, and paleomagnetic constraints upon the Neoproterozoic climatic paradox. American Journal of Science 300, 347-433.

Gevers, T.W., 1931. An ancient tillite in South-West Africa. Transactions of the Geological Society of South Africa 34, 1-17.

Grotzinger, J.P., James, N.P., 2000. Precambrian carbonates; evolution of understanding. Carbonate sedimentation and diagenesis in the evolving Precambrian world. In: Grotzinger, J.P., James, N.P. (Eds.), SEPM (Society for Sedimentary Geology) Special Publication 67. Tulsa, pp. 3-20.

Gunasekaran, S., Anbalagan, G., Pandi, S., 2006. Raman and infrared spectra of carbonates of calcite structure. Journal of Raman Specstroscopy 37, 892899.

Halverson, G.P., Hoffman, P.F., Schrag, D.P., Maloof, A.C., Rice, A.H.N., 2005. Toward a neoproterozoic composite carbon-isotope record. Geological Society of America Bulletin 117 (9), 1181-1207.

Hedberg, R.M., 1979. Stratigraphy of the Owamboland Basin, South West Africa Bulletin. Precambrian Research Unit, Cape Town, 325 pp.

Hegenberg, W., 1987. Gas escape structures in Precambrian peritidal carbonate rocks. Geological Survey of South West Africa/Namibia Communications 3, 49-55.

Hoffman, P.F., 2002. Carbonates bounding glacial deposits: evidence for Snowball Earth episodes and greenhouse aftermaths in the Neoproterozoic Otavi Group of northern Namibia, Excursion Field Guide. In: Proceedings of the 16th International Sedimentological Conference, Auckland Park, South Africa, p. 39.

Hoffman, P.F., Halverson, G.P., 2008. Otavi Group of the Northern Platform and the Northern Margin Zone. In: Miller, M.R. (Ed.), Handbook of Namibian Geology. Geological Survey of Namibia, Windhoek.

Hoffman, P.F., Kaufman, A.J., Halverson, G.P., 1998. Comings and goings of global glaciations on a Neoproterozoic tropical platform in Namibia. GSA Today 8, $1-9$.

Hoffman, P.F., Hawkins, D.P., Isachsen, C.E., Bowring, S.A., 1996. Precise U-Pb zircon ages for early Damaran magmatism in the Summas Mountains and Welwitschia Inlier, northern Damara belt, Namibia. Communications of the Geological Survey of Namibia 11, 47-52.

Hoffman, P.F., Li, Z.-X., 2009. A palaeogeographic context for Neoproterozoic glaciation. Palaeogeography, Palaeoclimatology, Palaeoecology 277, 158-172.

Hoffman, P.F., Schrag, D.P., 2002. The snowball Earth hypothesis; testing the limits of global change. Terra Nova 14, 129-155.

Hoffmann, K.-H., Prave, A.R., 1996. A preliminary note on a revised subdivision and regional correlation of the Otavi Group based on glaciogenic diamictites and associated cap dolostones. Communications, Geological Survey of Namibia 11, 77-82.

Hoffmann, K.H., Condon, D.J., Bowring, S.A., Crowley, J.I, 2004. U-Pb zircon date from the Neoproterozoic Ghaub formation, Namibia: constraints on Marinoan glaciation. Geology 32, 817-820. 
Hurtgen, M.T., Arthur, M.A., Suite, N.S., Kaufman, A.J., 2002. The sulfur isotopic composition of Neoproterozoic seawater sulfate: implications for a Snowball Earth? Earth and Planetary Science Letters 203, 413-429.

James, N.P., Narbonne, G.M., Kyser, T.K., 2001. Late Neoproterozoic cap carbonates; Mackenzie Mountains, northwestern Canada; precipitation and global glacial meltdown. Canadian Journal of Earth Sciences 38 (8), 1229-1262.

Kaufman, A.J. Varni, M.A. Hebert, C.L., Wing B., Misi, A., Babinski, M., Halverson, G.P. Corsetti, F.A., 2003. Carbon isotopic evidence for Neoproterozoic glacial cycles driven by iron- and phosphorous-stimulated productivity. In: South American Symposium of Isotope Geology IV, Salvador de Bahia, Brazil, pp. 359-360.

Kennedy, M.J., Christie-Blick, N., Sohl, L.E., 2001. Are Proterozoic cap carbonates and isotopic excursions a record of gas hydrate destabilization following Earth's coldest intervals? Geology 29 (5), 443-446.

Le Roex, H.D., 1941. A tillite in the Otavi Mountains. S.W.A. Transactions of the Geological Society of South Africa 44, 207-221.

Macdonald, F.A., Jones, D.S., Schrag, D.P., 2009a. Stratigraphic and tectonic implications of a new glacial diamictite-cap carbonate couplet in southwestern Mongolia. Geology 37, 123-126.

Macdonald, F.A., McClelland, W.C., Schrag, D.P., Macdonald, W.P., 2009b. Neoproterozoic glaciation on a carbonate platform margin in Arctic Alaska and the origin of the North Slope subterrane. Geological Society of America Bulletin 121, 448-473.

Miller, R.M., 1983. The Pan-African Damara Orogen of South West Africa/Namibian. In: Miller, R.M. (Ed.), Evolution of the Damara Orogen. Special Publication of the Geological Society of South Africa, pp. 431-515.

Pasteris, J.D., Wopenka, B., 2003. Necessary, but not sufficient: Raman identification of disordered carbon as a signature of ancient life. Astrobiology 3 (4), 727-738.

Pruss, S.B., Fraiser, M.L., Bottjer, D.J., 2004. The global proliferation of Early Triassic wrinkle structures: implications for environmental stress following the endPermian mass extinction. Geology 32, 461-464.
Rodrigues-Nogueira, A.C., Ricconimi, C., Sial, A.N., Veloso-Moura, C.A., Fairchild, T.R., 2003. Soft-sediment deformation at the base of the Neoproterozoic Puga cap carbonate (south-western Amazon craton, Brazil): confirmation of rapid icehouse to greenhouse transition in snowball Earth. Geology 31, 613-616.

Schieber, J., et al., 2007. Atlas of Microbial Mat Features Preserved Within the Clastic Record. Elsevier, 288 pp.

Schroeder, S., Beukes, N.J., Sumner, D.Y., 2009. Microbialite-sediment interactions on the slope of the Campbellrand carbonate platform (Neoarchean, South Africa). Precambrian Research 169, 68-79.

Simonson, B.M., Carney, K.E., 1999. Roll-up structures; evidence of in situ microbial mats in late Archean deep shelf environments. Palaios 14, 13-24.

Stakes, D.S., Orange, D., Paduan, J.B., Salamy, K.A., Maher, N., 1999. Cold-seeps and authigenic carbonate formation in Monterey Bay, California. Marine Geology 159, 93-109.

Stephens, N.P., Sumner, D.Y., 2002. Renalcids as fossilized biofilm clusters. Palaios $17,225-236$

Sumner, D.Y., 1997. Carbonate precipitation and oxyegn stratificatin in late Archea seawater as deduced from facies and stratigaphy of the Gamohaan and Frisco formations, Transvaal Supergroup, South Africa. American Journal of Science $297,455-487$.

Tucker, M.E. 1983. Diagenesis, geochemistry, and origin of a Precambrian dolomite: the Beck Spring Dolomite of Eastern California. Journal of Sedimentary Research 53, 1097-1119.

Turner, E.C., James, N.P., Narbonne, G.M., 2000. Taphonomic control on microstruc ture in Early Neoproterozoic reefal stromatolites and thrombolites. Palaios 15 , 87-111.

Yoshioka, H., Asahara, Y., Tojo, B., Kawakami, S., 2003. Systematic variations in C $\mathrm{O}$, and $\mathrm{Sr}$ isotopes and elemental concentrations in Neoproterozoic carbonates in Namibia: implications for a glacial to interglacial transition. Precambrian Research 124, 69-85. 